\title{
Kentsel Dönüşüm Strateji Belgelerinde Sürdürülebilirlik Değerlendirmesi: Kilis Örneği
}

\author{
Zeliha ÖZEL MAZLUM $^{1 *}$ ve Özge YALÇINER ERCOŞKUN ${ }^{2}$
}

Öz

Türkiye jeolojik konumu, topoğrafik ve meteorolojik özelikleri nedeniyle doğal afetlerle karşı karşıya olan bir ülkedir. Başta deprem olmak üzere, olası afetlerde oluşacak zararların azaltılarak yaşam kalitesinin artııımasına ve yapıların çevresi ile birlikte değerlendirilerek donatı alanı ihtiyacının da giderilmesine yönelik afet riski altındaki alanlarda kentsel dönüşüm gerçekleştirilmektedir. Günümüze kadar gerçekleştirilen kentsel dönüşüm uygulamaları ile yalnızca fiziksel çevrenin iyileştirilmesi amaçlanmıştır. Ancak kentsel dönüşüm fiziksel çevrenin iyileştirilmesinin yanı sıra; ekolojik, mekansal, ekonomik ve sosyal sürdürülebilirliğin sağlanması açısından da fırsatlar sunmaktadır. Kentsel dönüşüm sürecinin iyileştirilmesi ile kentsel dönüşümün bütüncül bir şekilde yönetilmesini sağlamak amacıyla il ve ilçe ölçeğinde idareler tarafından kentsel dönüşüm strateji belgesinin hazırlanması zorunlu kılınmıştır. Bu kapsamda Kilis Kentsel Dönüşüm Strateji Belgesi'nde yer verilen stratejilerin ulusal ve uluslararası çalışmalar ile uyumluluğunu test etmek üzere uyumluluk matrisleri hazırlanmıştır. Uyumluluk matrislerinin değerlendirilmesi sonucunda, idareler tarafından hazırlanması zorunlu kılınan, kentsel dönüşüm strateji belgelerinde yer alması gereken sürdürülebilirlik ilkeleri belirlenmiştir.

Anahtar Kelimeler: Kilis, kentsel dönüşüm, strateji belgesi, sürdürülebilirlik

\section{Sustainability Assessment in Urban Transformation Strategy Paper: Kilis Case}

\begin{abstract}
Turkey is continuously at the risk of natural disasters due to its geological location, meteorological and topography characteristics. Urban transformation is used both to reduce the potential damages of natural hazards especially earthquakes and also to improve the quality of living standards in areas under disaster risk.Thus far, the urban transformation projects completed in Turkey are solely aimed to improve physical environment quality. However, urban transformation may also present many opportunities for ensuring ecological, spatial, economic, social and cultural sustainability beside physical environment quality improvement. This crucial need of improvement in urban transformation operations should be managed with a holistic approach and therefore, the preparation of "urban transformation strategy paper" by local government (municipalities) becomes mandatory. This paper compares the standards of Kilis Urban Transformation Strategy Paper with national and international studies and creates "compatibility matrices". The result determined the sustainability criteria which should be included in all urban transformation strategy papers that will be consequently prepared by the municipalities.
\end{abstract}

Keywords: Kilis, urban transformation, strategy paper, sustainability

\footnotetext{
${ }^{1}$ Yüksek Lisans Öğrencisi. Gazi Üniversitesi, Şehir ve Bölge Planlama Anabilim Dalı, Ankara, Türkiye

${ }^{2}$ Prof. Dr. Gazi Üniversitesi, Şehir ve Bölge Planlama Anabilim Dalı, Ankara, Türkiye

*ilgili yazar / Corresponding author: zzeliha.ozel@gmail.com 


\section{Giriş}

Ülkemizde yürütülen kentsel dönüşüm uygulamaları genel itibarı ile 6306 sayılı Afet Riski Altındaki Alanların Dönüştürülmesi Hakkında Kanun, 5393 sayılı Belediye Kanunu ve 5366 sayııı Yıpranan Tarihi ve Kültürel Taşınmaz Varlıkların Yenilenerek Korunması ve Yaşatılarak Kullanılması Hakkında Kanun uyarınca belirlenen alanlarda gerçekleştirilmektedir. 5393, 5366 ve 6306 sayılı Kanunlar uyarınca alanların kentsel dönüşüm kapsamına alınmasına yönelik talepler, ilgili mevzuatları gereği alan tespiti ve uygulama yapmaya yetkili büyükşehir belediyesi veya ilçe belediyelerinin talebi üzerine Çevre ve Şehircilik Bakanlığınca değerlendirilmektedir.

6306 sayılı Kanunun 1. maddesinin birinci fıkrasında; "Bu Kanunun amacı, afet riski altındaki alanlar ile bu alanlar dışındaki riskli yapıların bulunduğu arsa ve arazilerde, fen ve sanat norm ve standartlarına uygun, sağılılı ve güvenli yaşama çevrelerini teşkil etmek üzere iyileştirme, tasfiye ve yenilemelere dair usul ve esasları belirlemektir." hükmü yer almaktadır. Çevre ve Şehircilik Bakanlığı 2023 vizyonu kapsamında, kentsel dönüşüm uygulamalarında karşılaşılan sorunların çözümü, dönüşüm sürecinin iyileştirilmesi ile yerleşim ölçeğindeki kentsel dönüşümün sürdürülebilir ve bütüncül bir şekilde yönetilmesini sağlamak amacıyla yeni bir yaklaşıma ihtiyaç duyulmuştur. Bu kapsamda dönüşüm uygulamalarını yönlendirecek olan "Kentsel Dönüşüm Strateji Belgesinin Hazırlanmasına Yönelik Illke ve Esaslar" 19.02.2019 tarihinde Bakanlık Makamınca onaylanmıştır. Bu tarihten itibaren yapılacak olan tüm kentsel dönüşüm alanı tekliflerinin değerlendirilebilmesi için il/ilçe genelinde Kentsel Dönüşüm Strateji Belgesi'nin hazırlanarak Bakanlığın uygun görüşünün alınmış olması gerekmektedir. Teklif edilen alanın Kentsel Dönüşüm Strateji Belgesinde önceliklendirilen alanlar arasından seçilmiş olması şartı aranacaktır (Kentsel Dönüşüm Strateji Belgesinin Hazırlanmasına Yönelik İlke ve Esaslar, Çevre ve Şehircilik Bakanlı̆̆ı, 2019).

2019 yılı içerisinde hazırlanan "Kentsel Dönüşüm Strateji Belgesi Hazırlanmasına Yönelik İlke ve Esaslar" öncesinde de Bakanlık tarafından seçilen alanlara ilişkin strateji belgeleri hazırlanmıştır. 04/01/2015 tarihli ve 29236 sayılı Mükerrer Resmi Gazete'de yayımlanarak 2015 Yılı Yatırım Programı kapsamına alınan Kilis ve Elazığ İllerine ilişkin strateji belgesi hazırlanması için kaynak ayrılmıştır. Dönüşüm Projeleri Özel Hesabı'ndan ayrılan bütçe ile de; Elazığ İli ve İstanbul İli, Gaziosmanpaşa İlçesi'nde Master Plan hazırlanmıştır (Çevre ve Şehircilik Bakanlığı Arşivi, 2019).

Gelecek kuşakların ihtiyaçları göz önünde bulundurulduğunda, kentsel dönüşüm uygulamaları ile imar mevzuatına aykırı yapılaşan yapıların yer aldığı kentlerin sürdürülebilir kentlere dönüştürülmesi gerekmektedir. Çevre ve Şehircilik Bakanlığı tarafından hazırlanan ve İdarelerce hazırlanması zorunlu kılınan kentsel dönüşüm strateji belgesinin sürdürülebilir kentlerin oluşturulması açısından değerlendirildiğinde, fırsat oluşturduğu düşünülmektedir.

\section{KILIS MEVCUT DURUM ANALIZi}

Kilis İli'nde ekonomik ömrünü tamamlamış yapı stoku barındıran alanlar yer almaktadır. Kentin nüfus artışı ile birlikte plansız kentleştiği, sosyal ve teknik altyapı yetersizliğinin yaşam kalitesini düşürdüğü ve bunların yanı sıra yoksulluk, sosyal dışlanmışlık ve güvensizlik vb. sosyal problemlerin yaşandığı tespit edilmiştir (Kilis Kentsel Dönüşüm Strateji Belgesi, 2015). Bu sebeple, örnek olarak Kilis İli, Merkez İlçesi, 2330 hektar yüzölçümüne sahip alana ilişkin (Şekil 1,2) hazırlanan Kilis Kentsel Dönüşüm Strateji Belgesi incelenmiştir. Bakanlık ile Kilis Belediye Başkanlığı arasında imzalanan protokol kapsamında Kentsel Dönüşüm Strateji Belgesi hazırlanması işine yönelik hizmet alımı yapılmıştır. Hizmet alımı kapsamında belge planlama-mimarlık ofisi tarafından hazırlanmıştır. 


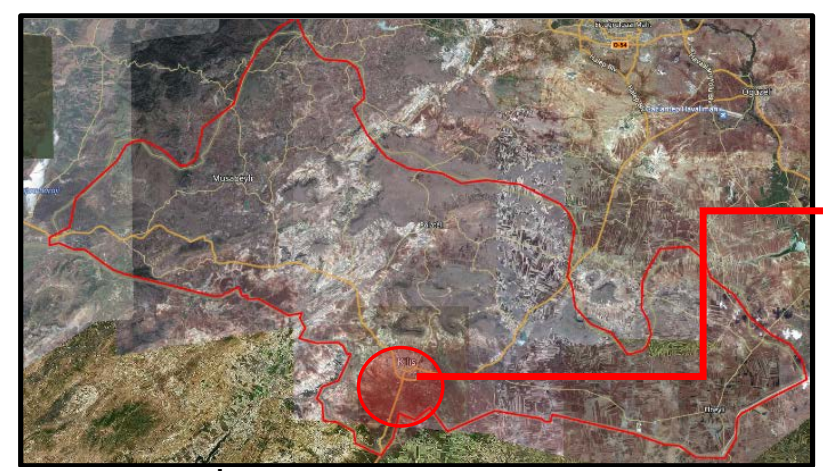

Şekil 1. Kilis İ Sınırı (Google Earth, 2019)

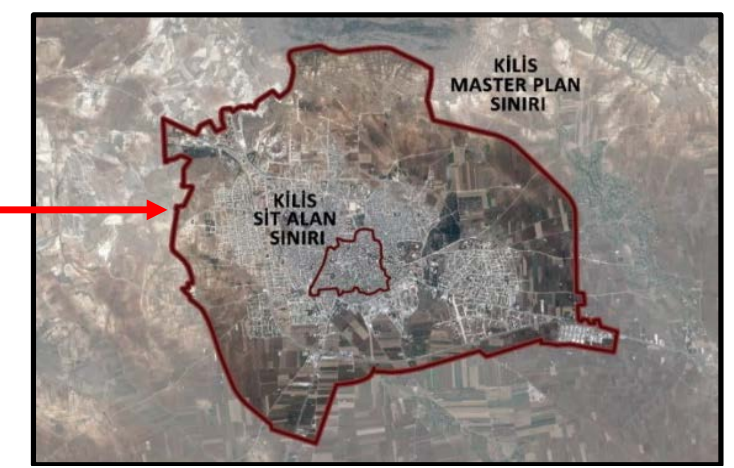

Şekil 2. Kentsel Dönüşüm Strateji Belgesi Sınırı (Kilis Kentsel Dönüşüm Strateji Belgesi, 2015)

Kilis İli'nde Merkez İlçe ile birlikte Polateli, Musabeyli ve Elbeyli İlçeleri yer almaktadır. Ülkenin Suriye'ye açılan kapısı niteliğinde olan Kilis, Suriye'de yaşanan iç savaş dolayısıyla yaşanan göç dalgasından etkilenmiştir. Göç nedeniyle illegal yapılaşan alanların ortaya çıkması, donatı alanı yetersizliği, sanayi alanların kent içerisinde kalması ve verimli tarım topraklarının işgal edilmesi vb. gerekçeler kentsel dönüşümü gerekli kılmıştır. Kilis İli'nde en büyük nüfus kırılmalarından biri 2011 yılı itibariyle yaşanan Suriyeli göçüdür. Strateji Belgesinin hazırlandığı 2015 yılında AFAD'dan alınan verilere göre 13.08.2015 tarihi itibariyle Kilis kent merkezinde 71.889, kamplarda 34.821 kişi olmak üzere toplam 106.710 kişi yaşamaktadır. 2019 yılı itibariyle Kilis'te yaşayan Suriyeli sayısı 114.797 dir (https://multeciler.org.tr/turkiyedeki-suriyeli-sayisi/). TUíK verilerine göre $2018 \mathrm{Kilis}$ İli nüfusu ise; 142.541'dir (Tablo 1).

Tablo 1. Kilis İli Nüfus Bilgileri (TUİK,2019)

\begin{tabular}{|r|r|r|r|r|r|r|r|r|r|r|}
\hline $\mathbf{2 0 0 8}$ & $\mathbf{2 0 0 9}$ & $\mathbf{2 0 1 0}$ & $\mathbf{2 0 1 1}$ & $\mathbf{2 0 1 2}$ & $\mathbf{2 0 1 3}$ & $\mathbf{2 0 1 4}$ & $\mathbf{2 0 1 5}$ & $\mathbf{2 0 1 6}$ & $\mathbf{2 0 1 7}$ & $\mathbf{2 0 1 8}$ \\
\hline 120991 & 122104 & 123135 & 124452 & 124320 & 128586 & 128781 & 130655 & 130825 & 136319 & 142541 \\
\hline \hline
\end{tabular}

TUİK'ten alınan verilere göre; Strateji Belgesi'nin hazırlandığı 2015 tarihinde nüfusun yaş ve cinsiyet değişkenlerine göre dağılımı incelendiğinde; kadın ve erkek sayısının birbirine yakın olduğu tespit edilmiştir. Kentte çalışabilir nüfusun bulunduğu, yaşı nüfusuna oranla 20-30 yaş arası genç sayısının fazla olduğu gözlemlenmiştir (Kilis Kentsel Dönüşüm Strateji Belgesi, 2015).

Tablo 2. Kilis İli 2015 Yılı Nüfusa Göre Yaş Dağılımı (TUIKK, 2019)

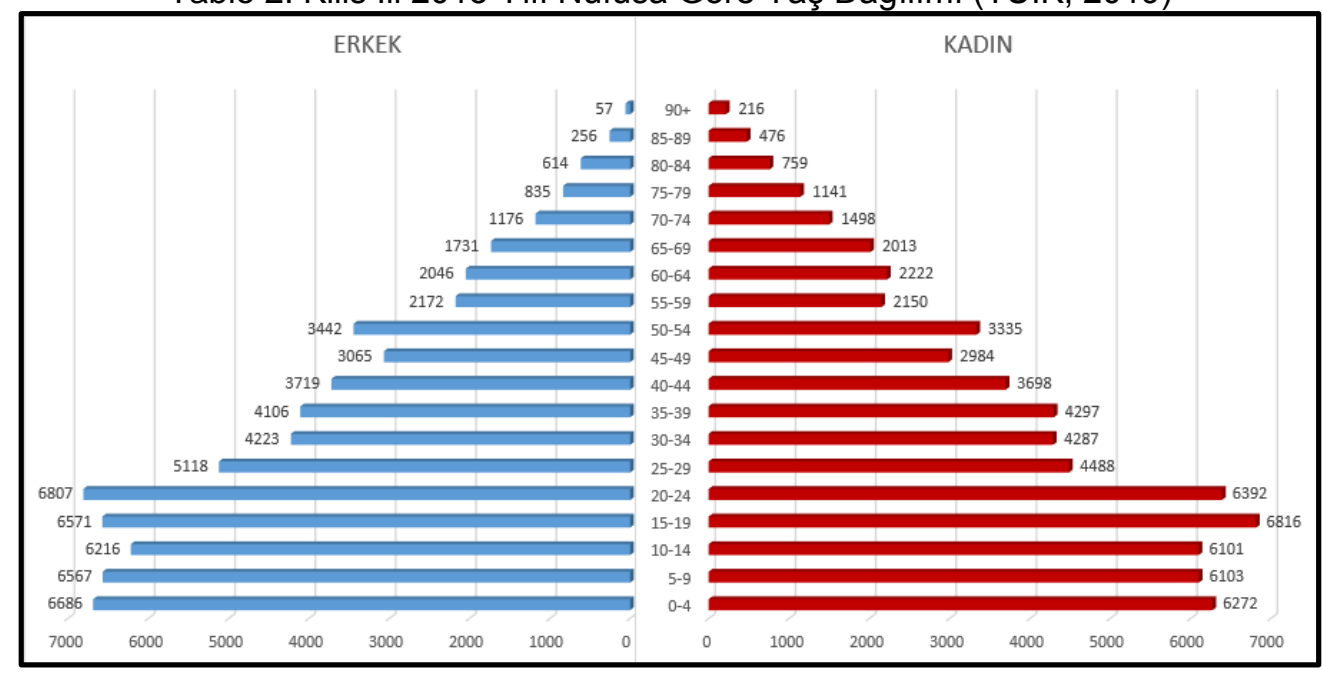


Kilis'te tarım, hayvancılık, sanayi ve sınır ticareti bölgenin ekonomik değerlerini oluşturmaktadır. Bölgenin tarım topraklarının organik tarım üretim şekline elverişli olması, sektörün bu kolda gelişmesini sağlamaktadır (TC1 Bölge Planı, 2015). Tablo 3'te Kilis İli'nde yer alan çiftçi sayısı yer almaktadır.

Tablo 3. Yıllara Göre Değişen Çiftçi Sayısı (TUiK,2019)
\begin{tabular}{|c|c|c|c|}
\hline $\mathbf{2 0 1 5}$ Yılı & $\mathbf{2 0 1 6}$ Yılı & $\mathbf{2 0 1 7}$ Yılı & $\mathbf{2 0 1 8}$ Yılı \\
\hline 460 & 484 & 522 & 148 \\
\hline
\end{tabular}

Kilis Kentsel Dönüşüm Strateji Belgesi kapsamında hazırlanan analizler incelendiğinde; kent genelinde aktif yeşil alanların niceliksel olarak eksik olduğu tespit edilmektedir. Kentte kişi başına 3,71 $\mathrm{m}^{2}$ yeşil alan düşmektedir. Yeşil alanların yanı sıra; kentte sağlık ve eğitim tesisi alanı da yetersiz kalmaktadır. Özellikle yeni yapılaşan alanlarda kişi başına $1 \mathrm{~m}^{2}$ eğitim ve sağlık alanı düşmektedir (Kilis Kentsel Dönüşüm Strateji Belgesi, 2015). Yapılaşma eğilimi incelendiğinde, verimli tarım arazileriyle çevrili kentin güneyine ve doğusuna bir yönelim olduğu görülmektedir (Şekil 3,4, 5).

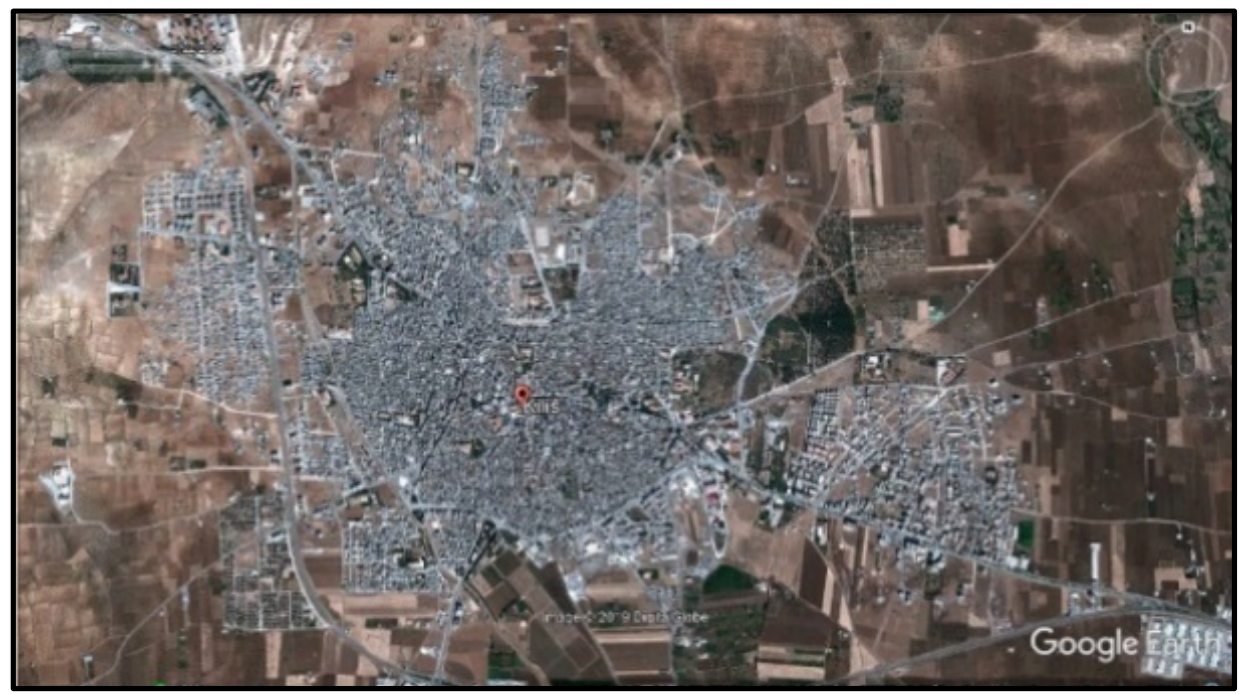

Şekil 3. 2009 Uydu Görüntüsü

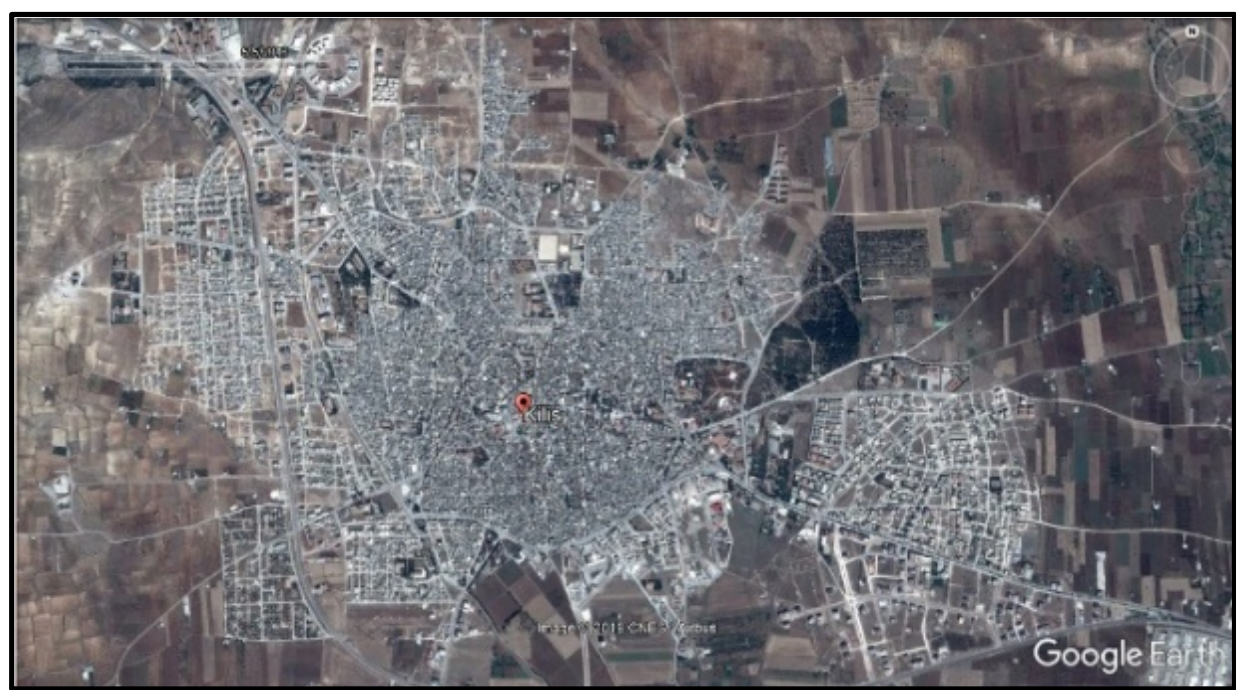

Şekil 4. 2013 Uydu Görüntüsü 


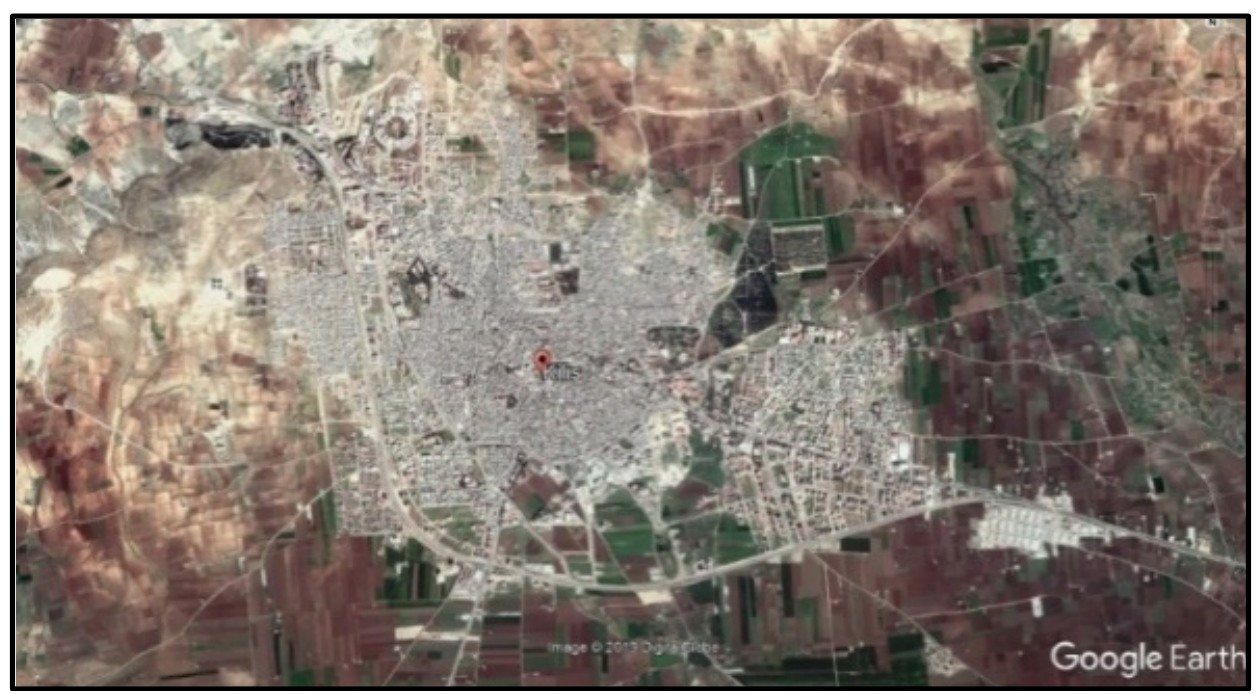

Şekil 5. 2019 Uydu Görüntüsü

6306 sayılı Kanunda rezerv yapı alanı; "Bu Kanun uyarınca gerçekleştirilecek uygulamalarda yeni yerleşim alanı olarak kullanılmak üzere, TOKI'nin veya İdarenin talebine bağlı olarak veya resen Bakanlıkça belirlenen alanlar" olarak tanımlanmaktadır. Kilis İli, Merkez İlçesi'nde Çevre ve Şehircilik Bakanlığınca belirlenen toplam 386.2 hektar yüzölçümüne sahip 3 adet rezerv yapı alanı bulunmaktadır (Çevre ve Şehircilik Bakanlığı Arşivi, 2019). Kentte göç ile birlikte nüfusun artışı yeni konut alanlarının oluşturulmasını gerekli kılmıştır. Bu sebeple Bakanlıkça yeni yerleşim alanlarının oluşturulmasına yönelik rezerv yapı alanları belirlenmiştir.

\section{YÖNTEM}

Sanayileşme ve hızlı kentleşmenin hız kazanması ile birlikte doğal kaynakların bilinçsizce tüketimi, ekolojik kaygıların artmasına neden olmuştur. Böylelikle sürdürülebilir kentleşmenin desteklenmesi amaçlanarak, uluslararası çalışmalar ile sürdürülebilirlik yaklaşımları benimsenmeye başlamıştır. Topoğrafyaya saygılı, iklime duyarlı tasarımları destekleyen, biyoçeşitliliğin korunmasını hedefleyen, geri dönüşüm ve kompakt yerleşimlere teşvik eden Stephen $\mathrm{M}$. Wheeler yaklaşımları ile birlikte sürdürülebilir kalkınma ve çevreye ilişkin hususların tartışıldığı Gündem 21 sürdürülebilir kentleşme açısından değerlendirildiğinde önem arz etmektedir.

Belirtilen sebeple; sürdürülebilir kalkınmayı amaçlayan Kilis Kentsel Dönüşüm Strateji Belgesi'nde yer verilen stratejilerin, Gündem 21'de tartışılan konular ve Stephen M. Wheeler tarafından belirlenen sürdürülebilir planlama yaklaşımları ile uyumluluğu test etmek üzere uyumluluk matrisleri hazırlanmıştır (Akgün, 2014). Uyumluluk matrislerinin değerlendirilmesi sonucunda kentsel dönüşüm strateji belgelerinde yer alması gereken sürdürülebilirlik ilkeleri belirlenmiştir.

\section{ULUSLARASI LITERATÜR}

\subsection{Gündem 21}

1992 Rio de Janeiro kentinde BM tarafından düzenlenen Çevre ve Gelişme Konferansı sonucunda kabul edilen Gündem 21 oluşumu sürdürülebilir kentleşme için önem taşımaktadır. Gündem 21, kalkınma ve çevre arasında denge kurulmasını hedefleyen sürdürülebilir gelişme kavramının yaşama geçirilmesine yönelik, küresel uzlaşmanın ve politik taahhütlerin en üst düzeyde tartışıldığı bir eylem planıdır. Eylem planının ana başlıkları sosyal ve ekonomik boyut, kalkınma için kaynakların korunması ve yönetimi, temel grupların 
rollerinin geliştirilmesi ve uygulama araçlarından oluşmaktadır. Gündem 21'de biyolojik kaynakların sürdürülebilir yönetimi ve kullanımı amacıyla genlerin, türlerin ve ekosistemlerin korunması ve sürdürülmesi için kararların alınması gerektiği belirtilmiştir. Aynı zamanda; su kaynaklarının korunması, su kalitesinin artırılması gerektiği ve kırsal kalkınma için su temininin önem arz ettiği hususlarına da yer verilmiştir. Gündem 21 ile fiziksel çevrenin yanı sıra sosyal çevreye ilişkin de kararlar alındığı görülmektedir. Kadınların karar alma süreçlerine aktif katılımlarının sağlanması ve çevreye duyarlı üretken faaliyetlere teşvik edilmesi gerektiği, gençler ve çocuklar için eğitim, sağlık vb. hizmetlerinin iyileştirilmesi ile birlikte istihdam fırsatlarının oluşturulması gerektiği savunulmuştur. Ekonomik, sosyal ve çevresel altyapıyı inşa eden yerel otoritelerin "yerel bir Gündem 21" benimsemesi gerektiği belirtilmiştir (Varol, Ercoşkun ve Gürer, 2011). Diğer taraftan, çiftçilerin motivasyonun artırıması ve eğitilmesi ile birlikte çiftçilere doğal kaynaklarını etkin bir şekilde yönetme konusunda teşvik sağlanması gerektiği konuları üzerinde durulmuştur (Agenda 21, 1992).

\subsection{Sürdürülebilir Planlama Yaklaşımları}

Wheeler, kentleri, yeşil, güvenli, insan ölçeğinde, kimlikli, çekici ve toplumun tüm bireyleri için, kadınlar, çocuklar, yaşlılar ve diğer gruplar için rahat kılmanın yolunu aramış (Wheeler, 2004); sürdürülebilir kentin bir ideal olduğunu belirtmiş, kentlerin tasarımında sürdürülebilirlik yolunda neler yapılması gerektiğini 9 maddede özetlemiştir:

- Derişik, etkili arazi kullanımı,

- Daha az araba kullanımı, daha çok erişebilirlik,

- Etkin kaynak kullanımı, daha az kirlilik ve atık,

- Doğal sistemlerin restorasyonu,

- İyi barınma ve yaşam çevreleri oluşturmak,

- Sağlıklı sosyal ekoloji,

- Sürdürülebilir ekonomi,

- Halkın katılımı,

- Yerel kültürü korumak.

Sürdürülebilir planlama ve tasarım konusunda yazında yer alan benzer ilkeler şu şekilde sıralanabilir (Newman ve Jennings, 2008, Holmgren, 2007, Kazimee, 2002, EU, 2004, Resilientcity website, Vergunst, 2002, Coaffee, 2008, Raven, 2010, Godschalk, 2003, Hopkins, 2008, UNISDR, 2010, Newman, Beatley ve Boyer, 2009, Hodson ve Marvin, 2009):

- Yoğunluğu, çeşitliliği, karma kullanımı desteklemek, yürüme mesafelerini planlamak,

- Yürümeyi, bisikleti, toplu taşımı ön plana çıkarmak, elektrikli taşıtlarla sera gazı salımlarını azaltmak,

- Trafiği sakinleştirme programlarıyla küçük ve yavaş çözümler sunmak,

- Güçlü kimliğe sahip mekân duygusu gelişmiş kentler tasarlamak,

- Havayı, suyu, toprağı ve biyoçeşitliliği koruyup zenginleştirmek,

- Yenilenebilir kaynakları ve hizmetleri kullanmak,

- Kentsel metabolizmada eko-verimlilik için girdi-çıktı dengesiyle bir döngü oluşturmak,

- Gıdada kendi kendine yeterlilik sağlamak, yakında yetiştirip üretmek, yerel gıda alıp yerel gıda yemektir.

Wheeler'a göre sürdürülebilir gelişme konuları; büyümenin denetlenmesi ve arazi kullanım planlaması, kentsel tasarım, konut, ulaşım, çevre koruma ve restorasyon, enerji ve malzeme kullanımı, yeşil mimarlık ve yapılaşma, eşitlik ve çevresel adalet, ekonomik gelişme ve nüfus başlıkları altında toplanmıştır (Wheeler, S. M.,2004,). 
Wheeler kentlerin ve banliyölerin dışa doğru büyümesinin engellemesi, tarım arazilerinin, doğanın korunması konularına değinmiştir. Kentlerin kompakt gelişimi ile sürdürülebilir gelişmenin destekleneceğini düşünmektedir. Wheeler'a göre sürdürülebilir kentsel tasarım ile otomobil bağımlıı̆ı azaltılarak kaynakların daha verimli kullanılması gerekmektedir. Konut kalitesinin ve kapasitesinin arttırılmasına yönelik konulara da değinen Wheeler toplumun her kesimi için konut üretilmesi gerektiğini düşünmektedir. Toplu taşıma alternatiflerinin geliştirilmesi, bireylerin bisiklet gibi çevre kirliliği yaratmayan ulaşım alternatiflerine yönlendirilmesi gerektiğini savunmaktadır. Çevre koruma ve restorasyon başlığında; ekosistemlerin korunması, toksik atıkların azaltıması, ozon tabakasının korunması ve iklim değişikliği ile mücadele konuları önemlidir. Bunun yanı sıra; atık malzemelerin yeniden kullanıldığı veya geri dönüştürüldüğü sistemlerin kurgulanması, bireylerin geri dönüşüme teşvik edilmesi gerektiği konuları üzerinde durulmuştur. Wheeler, yeşil binaların enerji verimliliği sağladığını savunarak yeşil bina ve yerleşimlere teşvikin önemli olduğunu dile getirmiştir (Wheeler, S. M.,2004 s. 66-79).

Nüfusa yönelik ise; yoksul kesimin sürdürülebilir geçim kaynaklarının belirlenmesi, karar alma süreçlerine katılımının sağlanması, temel ihtiyaçlara erişimin sağlanması gerektiği konuları üzerinde durmuştur. Kentler sürdürülebilir kalkınmaya elverişli ekonomik politikalara teşvik edilmeli ve aynı zamanda sürdürülebilir kalkınma için ekonomik büyüme sağlanırken fiziksel çevrenin de korunmasına yönelik stratejiler belirlenmelidir. Wheeler, ekonomik büyüme modellerinin çevresel ve sosyal sorunlara yol açmayacak şekilde kırsal ve kentsel alanlardaki yaşam kalitesinin artırılması için gerekli olduğunu savunarak, kendi kendine yeten toplulukların oluşturulması gerektiğinden bahsetmiştir (Wheeler, S. M.,2004 s. 80-82).

\section{KILIS KENTSEL DÖNÜŞÜM STRATEJi BELGESI}

Kilis Belediye Başkanlığı'ndan alınan bilgiye göre; Kilis kent merkezini kapsayan alana ilişkin hazırlanan 1/1.000 ölçekli Revizyon Uygulama İmar Planı 2013 yılında onaylanmıştır. Kilis Kentsel Dönüşüm Strateji Belgesi ile mevzii imar planı kararlarından bağımsız, üst ölçekli kararlar alınmıştır. Kamusal açık alanlar, kent merkezi, altyapı, sürdürülebilirlik, kültürel miras, ulaşım, sosyo-kültürel ve sosyo-ekonomik çevre, göçmenler, donatı alanları, kentsel riskin azaltılması, afet sonrası, konut stoku, kentsel sanayileşme ve ticaret hususlarına ilişkin sorun ve potansiyeller çerçevesinde hedef, strateji ve eylemler belirlenmiştir. Belirlenen hedef, strateji ve eylemler doğrultusunda alınan kararlar mekana yansıtılmıştır. Çalışma kapsamında sürdürülebilir kalkınmaya ilişkin kararlar incelenerek uluslararası literatür ile uyumu test edilmiştir.

Kentsel Dönüşüm Strateji Belgesi kapsamında yapılan mevcut durum analizleri sonucunda; Kilis'te heterojen dağılım gösteren birbirinden bağımsız yeşil alan ve meydanların kapasitesinin intiyacı karşılayacak büyüklükte olmadığı tespit edilerek, yeşil alanlar ile birlikte meydanların kalitesinin ve kapasitesinin artırımasına yönelik kararlar alınmıştır. Kentin kimliğini oluşturan meydanlar ile birlikte bütüncül bir yeşil sistem oluşturulmasına ilişkin alınan kararlar mekana yansıtılarak, meydanlar ile yeşil alanlar birlikte kurgulanmıştır. Aynı zamanda, kentte eksik olan donatı alanlarının kalitesinin ve kapasitesinin artırılmasına ilişkin olarak, Mekansal Planlar Yapım Yönetmeliği'nde belirtilen standartlara uygun olarak donatı kapasitesinin artırılması hedeflenmiştir. Kent merkezleri ile konut alanlarını birbirine bağlamak amacıyla dere yatakları boyunca daralıp genişleyen yeşil alanların, yaya yollarının ve bisiklet yollarının olduğu yeşil koridorların oluşturulması eylem olarak belirlenmiştir (Kilis Kentsel Dönüşüm Strateji Belgesi, 2015).

Göçmenlerin kente gelmesi ile birlikte ulaşım ve otopark sorunları artış göstermiştir. Bu sebeple, kent için bütüncül bir ulaşım sistemin geliştirilmesi, mevcut yolların geliştirilerek 
intiyaç doğrultusunda yeni ulaşım bağlantılarının belirlenmesi, toplu taşıma güzergâhlarının belirlenmesi ile birlikte otopark intiyacının giderilmesine yönelik hedef, strateji ve eylemler belirlenmiştir (Kilis Kentsel Dönüşüm Strateji Belgesi, 2015).

Mevcut nüfusun ihtiyaçlarına göre planlanmış olan Kilis'in altyapısı göç sonrası artan nüfusun intiyaçlarını karşılaya yetmemektedir. Özellikle su temini, çöp toplama ve ulaşım gibi hizmetlerin karşılanmasında sorun yaşanmaktadır (ORSAM Raporu, 2015, s. 12). Aynı zamanda kentin sorunları arasında atık suların içme ve kullanma suyuna karışması bulunmaktadır. Mevcut altyapı sisteminin güçlendirilmesine yönelik olarak; tehlikeli atık bertaraf tesislerinin kurulması, atıksu ve yağmur suyu sistemlerinin birbirinden ayrılması eylemleri belirlenmiştir. İklim değişikliği etkilerinin azaltılması hedeflenerek, öncelikle su ayak izinin azaltılmasına yönelik; su kalitesinin korunması, su tüketiminin azaltılması, içme suyu ile kullanma suyunun ayrıştığı sistemlerinin kullanılması, çift atık boru sistemine sahip sistemlerinin kullanılması ve yağmur suyunun değerlendirilmesine ilişkin hedef, strateji ve eylemler belirlenmiştir. Diğer taraftan enerji verimliliği sağlamak ve yapılaşmanın iklim değişikliği üzerindeki etkisini azaltmak da amaçlanmıştır. Kentsel ısı adası etkisini azaltıcı önlemler alan projeler ile birlikte cephe yeşillendirme projelerinin geliştirilmesi, rüzgar koridorlarının oluşturulması eylemleri belirlenmiştir. Potansiyel olarak değerlendirilen güneş enerjisinin, güneş panelleri ve fotovoltaik sistemlere teşviki ile kentsel alanlarda kullanılmasına ilişkin kararlara da yer verilmektedir. Ulaşımdan kaynaklanan sera gazı ve hava kirliliğini minimuma indirmek için ulaşımda karbon emilimini artırıcı eylemler belge içerisinde yer almaktadır (Kilis Kentsel Dönüşüm Strateji Belgesi, 2015).

ORSAM Raporuna göre; Türkiye'deki göçmenlerin etkileri arasında; etnik ve mezhepsel kutuplaşma, çocuk işçilerin sayısı ve suç oranın artması ile birlikte temel hizmetlerin kapasitesinin yetersiz kalması vb. bulunmaktadır. Göç ile birlikte Kilis sosyal dışlanmışlık, yoksulluk, işsizlik ve güvensizlik sorunları ile karşı karşıya kalmıştır. Kilis Kentsel Dönüşüm Strateji Belgesi kapsamında yoksulluk ve sosyal dışlanmaya en çok maruz kalan mahalleler tespit edilerek, alan özelinde stratejiler geliştirilmiştir. Alt gelir gruplarının yoğunlaştığı mahallerde istihdamın artırılması, altyapı ve konut kalitesinin artırılmasına yönelik kararlar alınmıştır. Diğer taraftan, sosyal dışlanmanın yoğun görüldüğü mahaller için ücretsiz kurslarla eğitime destek verilmesi, sosyal marketlerin kurulması, eğitim tesis sayısının artırılması vb. projeler geliştirilmesine yönelik kararlar da alınmıştır (Kilis Kentsel Dönüşüm Strateji Belgesi, 2015).

Belgede yer alan ekonomik kalkınmaya ilişkin stratejiler incelendiğinde; yöresel ürünlerin üretilerek pazarlanmasına ilişkin kararlara yer verildiği görülmektedir. Yapılaşmış çevreye ilişkin alınan kararlar incelendiğinde ise; ruhsatsız yapılaşmanın yoğun olduğu alanların dönüşümünü gerçekleştirmeye yönelik teklif riskli alanların belirlendiği görülmektedir (Şekil $6)$. 


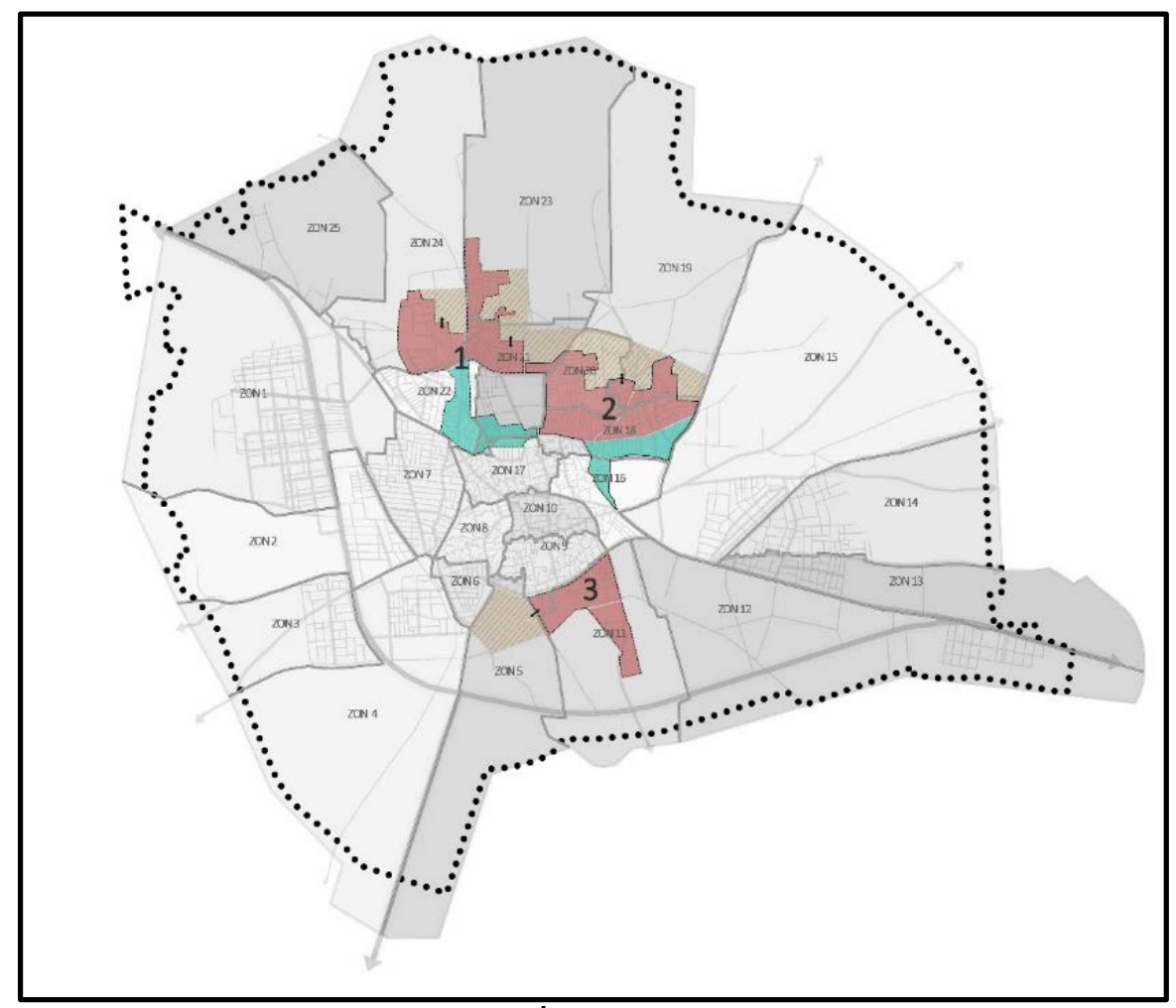

Şekil 6. Riskli Alan İlan Edilmesi Teklif Alanlar

Teklif riskli alanlarda 6306 Sayılı Kanunun Uygulama Yönetmeliği Ek-2 Riskli Yapıların Tespit Edilmesine İlişkin Esaslar ile belirlenen yönteme göre toplanan veriler doğrultusunda performans puanları hesaplanmıştır (Tablo 4).

Tablo 4.Teklif Riskli Alanlarda Muhtemel Risk Durumu (Kilis Kentsel Dönüşüm Strateji Belgesi, 2015)

\begin{tabular}{|c|c|c|c|c|c|}
\hline Risk Puanı & $\begin{array}{c}\text { Muhtemel } \\
\text { Risk Durumu }\end{array}$ & $\begin{array}{c}\text { 1 Kodlu } \\
\text { Teklif } \\
\text { Riskli Alan }\end{array}$ & $\begin{array}{c}\text { YAPI SAYISI } \\
\text { 2 Kodlu } \\
\text { Teklif } \\
\text { Riskli Alan }\end{array}$ & $\begin{array}{c}\text { 3 Kodlu } \\
\text { Teklif } \\
\text { Riskli Alan }\end{array}$ \\
\hline $\mathbf{3 5 - 1 3 2}$ & Çok & 151 & 640 & 875 \\
\hline $\mathbf{1 3 3 - 1 4 5}$ & Orta & 128 & 247 & 1193 \\
\hline $\mathbf{1 4 6 - 1 5 0}$ & Az & 29 & 50 & 55 \\
\hline \multicolumn{2}{r}{ Toplam } & 308 & 937 & 2123 \\
\hline
\end{tabular}

Kent genelindeki yapılaşma incelendiğinde, kentte yer alan 21.650 adet yapının \%83'ünün ruhsatsız olduğu tespit edilmiştir. Teklif riskli alanlar için hazırlanan ruhsat durumu tablosu aşağıda yer almaktadır (Tablo 5).

Tablo 5.Teklif Riskli Alanlarda Ruhsat Durumu (Kilis Kentsel Dönüşüm Strateji Belgesi, 2015)

YAPI SAYISI

\begin{tabular}{|c|c|c|c|}
\hline $\begin{array}{c}\text { Yapıların Ruhsat } \\
\text { Durumu }\end{array}$ & $\begin{array}{c}\text { 1 Kodlu } \\
\text { Teklif } \\
\text { Riskli Alan }\end{array}$ & $\begin{array}{c}\text { 2 Kodlu } \\
\text { Teklif } \\
\text { Riskli Alan }\end{array}$ & $\begin{array}{c}\text { 3 Kodlu } \\
\text { Teklif } \\
\text { Riskli Alan }\end{array}$ \\
\hline Ruhsatlı & 9 & 20 & 2 \\
\hline Ruhsatsız & 299 & 917 & 2121 \\
\hline Toplam & 308 & 937 & 2123 \\
\hline
\end{tabular}


Risk analizi sonuçlarına göre; illegal yapılaşma kentin kuzeyinde yoğunlaşmıştır. Bununla birlikte yapılan analizlere göre yerleşilebilirlik açısından en uygun alanların kentin kuzeyinde yoğunlaştığı görülmektedir. Kuzeydeki bölgeler zemin açısından daha sağlam olmakla birlikte, iklim açısından da daha elverişlidirler. Ayrıca buradaki alanların kentin geneline oranla daha eğimli bir topografyaya sahip olması manzara potansiyelini arttırmaktadır. Bu sebeple kentin kuzeyinde kentsel dönüşüm hedeflenmektedir. Şekil 7 incelendiğinde; kent gelişiminin kuzeye yönlendirildiği, kuzeyde yeni yolların önerildiği görülmektedir.

Kentsel risklerin azaltılmasına yönelik ise; teklif riskli alanlar ile teklif rezerv yapı alanları belirlenmiştir. Teklif rezerv yapı alanlarının önerilmesinin nedenleri arasında; kentin konut ihtiyacını gidermek üzere kente yeni konut alanları kazandırmak ve yoğun yapılaşmanın görüldüğü sit alanlarının yoğunluğunu azaltmak bulunmaktadır. Diğer taraftan; afet sonrasına ilişkin afet sonrası toplanma alanları, çadır kentler ve geçici barınma alanlarının belirlendiği görülmektedir.

Şekil 7'de yer alan Kilis Kentsel Dönüşüm Strateji Belgesi incelendiğinde; kente yeni meydanların kazandııılı̆̆ı, ticaretin geliştirildiği, yeşil koridorların oluşturulduğu, yaya ve araç yollarının yeniden düzenlendiği, eğitim ve sağlık alanlarının kapasitesinin artırıldığı ve korunacak alanlarının belirlendiği görülmektedir. Yeşil koridorlar ile bütüncül bir yeşil sistem oluşturmak, yaya dolaşımına sürdürülebilir bir alternatif oluşturmak hedeflenmiştir.

Meydanlar ve merkezlere ilişkin olarak, mevcut meydanlar işlevsel ve fiziksel açıdan iyileştirilmiş ve yeni toplanma alanları önerilmiştir. Özellikle sit alanlarında yer alan boşluklar meydan olarak değerlendirilmiştir. Yeni merkezler ve konut alt bölgeleri oluşturulmuştur. Mevcutta tanımsız ve düzensiz olarak bulunan merkezler kademelendirilmiştir. Kent merkezleri ile konut alanlarının arasında bağlayıcı koridorlar oluşturulmuştur. Bu kapsamda Şekil 7'de yer verilen Kentsel Dönüşüm Strateji Belgesi ile; meydanların işlevleri geliştirilmiş ve kent merkezlerinin canlandırılması hedeflenmiştir.

Kent içerisinde yer alan sanayi alanları kent çeperinde yer alan küçük sanayi bölgelerine taşındığı görülmektedir. Kent içerisinde sanayi alanlarının yarattığı sorunları çözmek üzere sanayi alanlarının desantrilizasyonunu sağlamak hedeflenmiştir. Kent merkezinde ticari birimlerin sayısı ise artırımıştır. Özellikle illegal yapılaşan teklif riskli alanlarda istihdamın artırılması amaçlanarak yeni ticari alanlar önerilmiştir. Kentsel ticaret ve sanayileşme ilişkilerinin yeniden düzenlendiği görülmektedir.

Kent içerisinde doğu ve güney yönlerinde yoğunlaşan tarım alanlarının korunması önem arz etmektedir. Şekil 7'de görüldüğü üzere, yapılaşmanın engellenmesinin mümkün olduğu, nitelikli tarım yapılabilecek bölgelerin imara kapatılmasına ilişkin kararlar alınmıştır. Kentsel Dönüşüm Strateji Belgesinde alınan kararlar doğrultusunda tarım topraklarının korunmasının amaçlanmış ve imara kapatılacak alanlar belirlenmiştir. 


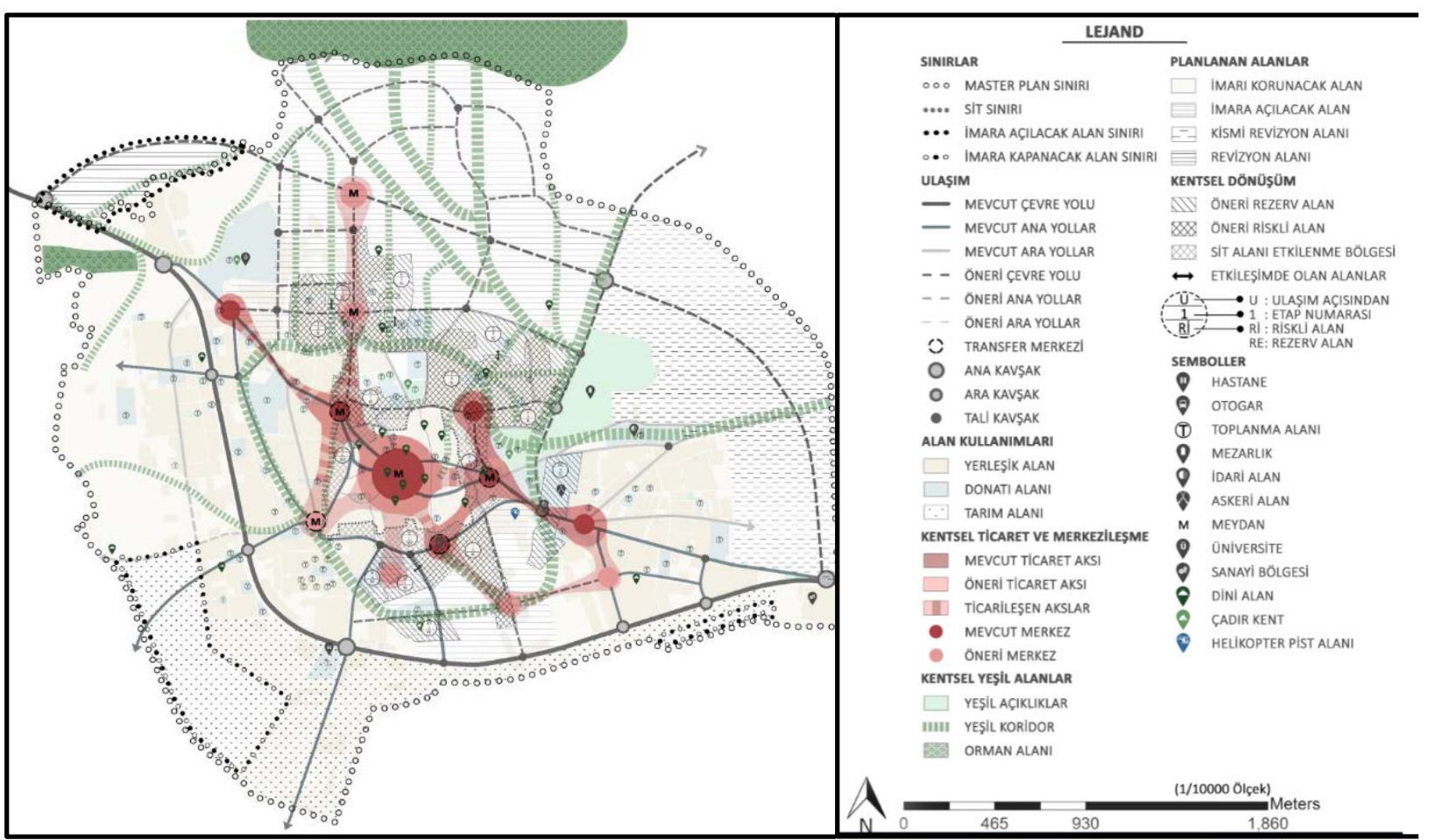

Şekil 7. Kilis Kentsel Dönüşüm Strateji Belgesi

\section{BULGULAR}

Gündem 21'in 4 eylem başlığı içerisinden; Kilis Strateji Belgesi'nde yer alan hedef, strateji ve eylemler ile karşılaştırılabilecek eylem başlıkları seçilmiştir. Seçilen ana başlıklar kalkınma için kaynakların korunması ve yönetimi ile birlikte temel grupların rollerinin geliştirilmesidir. Söz konu ana başlıklar altında yer alan; çölleşme ve kuraklık, biyolojik çeşitlilik, tatlısu kaynakları, kadınlar, çocuklar, gençler, yerel yönetimler ve çiftçilerin rollerinin güçlendirilmesi alt başlıkları ile birlikte; Wheeler'ın sürdürülebilir planlama başlıkları uyumluluk matrisine konu edilmiştir.

Kilis Kentsel Dönüşüm Strateji Belgesi'nde yer alan ve sürdürülebilir kalkınmayı hedefleyen konu başlıkları ile uluslararası çalışmalarda benimsenen sürdürülebilir kalkınmaya ilişkin konuların karşılaştırılması amaçlanarak uyumluluk matrisi hazırlanmıştır (Tablo 6).

Çölleşme, iklim değiş̧iklikleri ve insan faaliyetleri de dahil olmak üzere çeşitli faktörlerden kaynaklanan kurak, yarı kurak ve kuru nemli bölgelerde gerçekleşen bozulma olarak tanımlanabilir (http://www.cem.gov.tr, 2019). Küresel iklim değişikliği nedeniyle yaşanan aşırı yağışlar ya da kuraklıklar; su kaynaklarının verimli kullanılmasını, enerji verimliliğinin artııımasını, yapılaşmanın iklim değişikliği üzerindeki etkisinin azaltılmasını gerekli kılmaktadır. Kilis Kentsel Dönüşüm Strateji Belgesi'nde Gündem 21'de de özellikle vurgulanan çölleşme ve iklim değişikliği hususlarına ilişkin stratejilere yer verilmiştir. İklim değişikliği etkilerinin azaltılarak sürdürülebilir kalkınmayı sağlamak hedeflenmiştir. Kentsel ısı etkisini azaltan projelerin ve rüzgar koridorlarının oluşturulduğu, tarihi doku ve iklim özellikleri göz önünde bulundurularak tasarım ilkelerinin belirlendiği görülmektedir. Her ne kadar konut alanı ve yeşil alan tasarımlarımda iklim değişikliği etkisinin azaltılması amaçlanmış olsa da kent merkezleri ve ulaşım bağlantılarına ilişkin verilen kararların sürdürülebilirlik bileşenleri açısından değerlendirildiğinde yetersiz olduğu görülmektedir. 
Doğal çevrenin korunmasına ilişkin belirlenen stratejiler incelendiğinde ise; flora ve fauna çeşitliliğini ortaya koyan herhangi bir analize yer verilmediği tespit edilmiştir. Bu sebeple biyolojik çeşitliliğin korunmasına ilişkin herhangi bir hedef, strateji, eyleme de yer verilmemiştir. Biyolojik çeşitliliğin korunması başlığı değerlendirildiğinde belgenin uluslararası çalışmalar ile uyumsuz olduğu sonucu ortaya çıkmaktadır. Kilis'te nüfusun artmaya başlaması ile birlikte; su kalitesi ve hacmi açısından sorunlarla karşı karşıya kalınmıştır. Bu doğrultuda hazırlanan strateji belgesinde su ayak izinin azaltılmasına yönelik su kaynaklarının verimli kullanılması ve kalitesinin artırılmasına ilişkin konulara yer verilmiştir. Yeni yapılacak konutlarda su tüketimini azaltmaya ve su iletiminde içme suyu ile kullanma suyunun ayrıştığı sistemlerin kullanılmasına teşvik edecek karar alınmıştır.

Suriye'de yaşanan iç savaş nedeniyle Türkiye'ye göç eden yaklaşık 3 milyon göçmenin $\% 75$ 'inden fazlasını çocuklar ve kadınlar oluşturmaktadır (ORSAM Raporu, 2015, s. 12). Kilis'e göç ile gelen kadın ve çocuk sayısının erkek sayısından daha fazla olduğu göz önünde bulundurularak, dezavantajlı grupları oluşturan kadınların işgücüne katılımını sağlamak için projelerin geliştirilmesi yönünde kararlar alınmıştır. Kilis'te bulunan genç nüfus için yeni istihdam alanları oluşturacak çalışmaların yürütülmesine ilişkin stratejiler de belirlenmiştir. Temel grup olarak sayılabilecek kadın, genç ve çocuklar belgeye konu edilmiştir. Ancak belge çiftçiler ile yerel yönetimlerinin rollerinin belirlenmesi konularında yetersiz kalmaktadır. Uluslararası çalışmalar ile kentin intiyaç duyduğu hizmetleri sunacak ve planlama iş ve işlemlerini yürütecek olan yerel yönetimlerin rolleri tanımlanırken, Kilis Kentsel Dönüşüm Strateji Belgesinde yerel yönetimlerin görev ve sorumlulukları tanımlayacak yeterli düzeyde karara yer verilmediği tespit edilmiştir. Bunların yanı sıra; Kilis halkının kentsel dönüşüm, sürdürülebilirlik, çevre koruma ve iklim değişikliği hususlarında bilinçlendirilmesine yönelik eylemlere de yer verilmesi gerektiği düşünülmektedir.

Kilis kent genelinde kompakt bir yerleşimin geliştiği görülmektedir ancak rezerv yapı alanı belirlenerek yeni yerleşim alanlarının oluşturulması kararı Wheeler'ın kompakt gelişim yaklaşımına ters düşmektedir. Kilis Kentsel Dönüşüm Strateji Belgesi'nde verimli tarım arazilerinin amaç dışı kullanımını engelleyerek, korunmasının sağlayacak stratejiler yer almaktadır. Buna ek olarak; kentsel tasarım projeleri ile; kamusal alanların, sokakların, konutların tasarımının yanı sıra; park ve yeşil alanların, ulaşım bağlantıların, altyapı hizmetlerinin kurgulanması gerektiği hususlarına uluslararası çalışmalar ile vurgu yapılmıştır. Kilis Kentsel Dönüşüm Strateji Belgesinde kente kimliği yansıtan yeni meydanlar ve toplanma alanları kazandırmaya ilişkin strateji ve eylemler belirlenmiştir. Ancak çeşitli sokak tasarım teknikleri ile cadde ve sokakları keyifli hale getiren sürdürülebilirlik bileşenleri mekana yansıtmayı hedefleyen kentsel tasarım rehberlerine (Ercoşkun, Karaaslan, 2011) ve projelerine yer verilmemiştir.

Kent merkezinin dolmasıyla kentin güneyinde, kentten kopuk plansız konut alt bölgeleri oluşmaya başlamıştır. Bunun yanı sıra; yukarıda sunulduğu üzere yapılan analizler çalışma alanında bulunan yapı stoğunun \%83'ünün ruhsatsız olduğunu göstermektedir. Bu sebeple, kentsel dönüşüm ile ruhsatsız yapılaşan alanları dönüştürmek, konut kalitesini artırmak ve konut ihtiyacının karşılanmak için kararlar alınmıştır. Sağlıksız yaşam koşullarını iyileştirmek ve barınma intiyacını karşılamak amaçlanmış olsa da; yeşil mimarlığa teşvik eden kararların yer almadığı görülmektedir. Her ne kadar yeşil cephelerin oluşturulması, enerji verimliliğinin sağlanması gerektiği vb konularına değinmiş olsa da yeşil bina ve yerleşimlere yönlendiren yeterince stratejinin yer almadığı tespit edilmiştir.

Geri dönüşüm, yeniden kullanma ve malzeme kullanımın azaltılması sürdürülebilir kaynak kullanımı için önem arz etmektedir. Uluslararası çalışmalar ile; atık malzemelerin yeniden kullanıldığı veya geri dönüştürüldüğü sistemlerin kurgulanması gerektiği hususları üzerinde 
durulmuştur. Atıkların azaltılması ve yönetilmesi hususunda detaylı bilgiler Gündem 21 başlığı altında yer almaktadır. Kilis Kentsel Dönüşüm Strateji Belgesinde yenilebilir enerji kaynaklarının kullanılması ilişkin konulara yer verilmiştir. Ancak tüketim alışkanlıklarının değiştirilmesi, bireylerin atık yönetimi ve geri dönüşüm konusunda eğitilmesine ilişkin herhangi bir stratejiye yer verilmiştir.

Wheeler, yoksul kesimin sürdürülebilir geçim kaynaklarının belirlenmesi, karar alma süreçlerine katılımının sağlanması, temel ihtiyaçlara erişim ile birlikte; sağlık, eğitim vb. hizmetlere her kesimin kolaylıkla erişiminin sağlanması gerektiği üzerinde durmuştur. Böylelikle eşitlik ve çevresel adalet sağlanmış olacaktır. Kilis Kentsel Dönüşüm Strateji Belgesinde yoksullukla mücadeleye ilişkin belirlenen strateji ve eylemlerine incelendiğinde; kentin sosyal açıdan en önemli sorunlarının temelini, yoksulluk ve sosyal dışlanmanın oluşturduğu bu sebeple yoksullukla mücadeleye yönelik belirlenen strateji ve eylemlerin sayısının fazla olduğu tespit edilmiştir. Kilis Kentsel Dönüşüm Strateji Belgesinde belirlenen strateji ve eylemlere göre; öncelikle yerel idareler, sivil toplum kuruluşları ve muhtarların yaptıkları anket tespit ve araştırma sonuçlarında yoksul mahalleler tespit edilecektir. Yoksulluğun ve sosyal dışlanmanın yoğun görüldüğü mahallerde sağlık ve eğitim birimleri, halk eğitim merkezleri ve toplum merkezleri kurulacaktır. Yoksul mahallelerde eğitim ve sağlık birimleri oluşturulması ile birlikte aynı zamanda yoksul öğrencilere ücretsiz ders verecek kurslar oluşturulacak, öğrenciler için burs imkanları yaratılacaktır. Yardıma intiyacı olanların gelip ücretsiz faydalanabileceği içerisinde giyim, kitap, gıda, ev tekstili gibi ürünlerin bulunan sosyal marketler kurgulanacaktır. Evsizler ve sokak çocukları için acil durum barınakları, yemekhaneleri ve ayaküstü yardım merkezlerini de kapsayan rehabilitasyon merkezleri oluşturulacaktır. Strateji Belgesinde; sosyal farkındalığın yaratılması ve yoksulluk ve sosyal dışlanmaya maruz kalan alanların iyileştirilmesine yönelik kararların alındığı görülmektedir. Belgede yoksul kesimin ekonomiye entegrasyonu, yerel üretim yöntemlerinin geliştirilmesi, geleneksel ve yöresel ürünlerin oluşturulmasına ve üretilmesine konularını kapsayan kararlara da yer verilmiştir. Uyumluluk matrisi incelendiğinde; Wheeler'ın sürdürülebilir planlama yaklaşımı ile tam uyumlu olduğu sonucu ortaya çıkmaktadır.

Yoksulluk ve sosyal dışlanmışlık ile mücadele eden Suriyeli göçmenlerin sosyal ihtiyaçlarının giderilmesinin yanı sıra meslek sahibi olmalarına yönelik çalışmaların da gerçekleştirilmesi gerekmektedir. Belge göçmenlere ilişkin istihdam fırsatlarının oluşturulması ve göçmenlerin çevreye duyarlı üretken faaliyetlere teşvik edilmesi konusunda yetersiz kalmaktadır. Bunun yanı sıra; eğitim, sağlık vb. olanakların artırılması, göçmenlere psikolojik danışmanlık verilmesi, göçmenlerin Türkçe'yi öğrenmeleri için kursların açılmasına ilişkin kararlar alınması da önemlidir.

Göçmenlere yönelik kısa, orta ve uzun vadede gerçekleştirilecek olan faaliyetlerin hangi kurum ve kuruluşun görev ve sorumluluğunda olduğu belirtilmemiştir. Kaynakların etkin yönetilebilmesi için göç yönetiminin doğru şekilde planlaması gerekmektedir. Göçmen entegrasyonunu kolaylaştırmak için uyum politikaları geliştirilmelidir. 
Tablo 6. Uyumluluk Matrisi

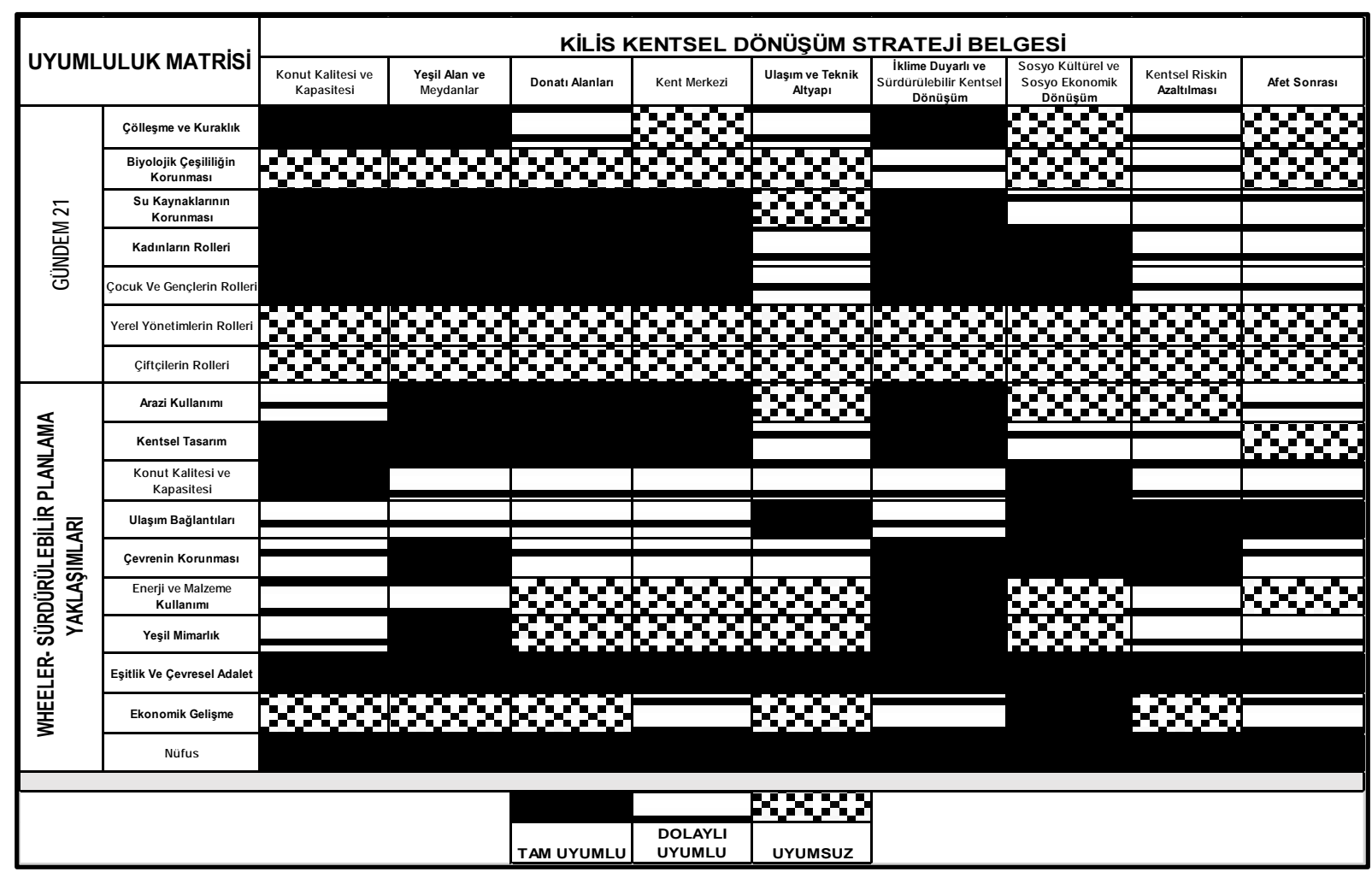

\section{SONUÇ ve ÖNERILER}

Ülke sınırında konumlanan Kilis'e yaşanan göç ile birlikte sosyal, ekonomik ve çevresel açıdan kent birçok sorunla karşılaşmıştır. Mevcut nüfusa altyapı sistemi, konut stoku ve donatı alanları yetersiz gelmektedir. Kilis'te nüfus artışı ile birlikte etnik kutuplaşma, yoksulluk, suç oranı artışı, altyapı hizmetleri yetersizliği, plansız yapılaşma vb. sorunlar ortaya çıkmıştır.

Kentte göç olgusuyla beraber konut alanları hızla yayılmış ve bu gelişim, teknik altyapı hizmetlerini zorlamaya başlamıştır. Kent içi ulaşımda taşıt sayısındaki artış ve sınır ticaretinden dolayı kent merkezindeki yoğunluk, ulaşımda sorunlarını beraberinde getirmiştir. Konut alanlarının plansız gelişmesi sonucu dönüşüme intiyaç duyan yerleşim alanlarının ortaya çıkması, kentsel dönüşümü gerekli kılmıştır.

Kilis'in sahip olduğu tarihsel ve kültürel değerlerin korunması ve geleceğe taşınması, alanın bir bütün olarak afet risklerinden uzak, sağlıklı ve güvenli bir yerleşim alanına dönüştürülmesi amacıyla üst ölçek planlar ile uyumlu, sürdürülebilir, iklim duyarlı, ekolojik, afet öncelikli, tarihi değerlere saygılı, katılımcı, çok aktörlü bir planlama yaklaşımı benimsenerek, 2330 hektarlık alana ilişkin 'Kentsel Dönüşüm Strateji Belgesi' hazırlanmıştır.

Kilis'in konumu, topografyası ve iklimine ilişkin bilgileri de göz önünde bulundurularak, arazi yapısı ve iklim özelliklerine uygun kararlar alınmıştır. Bahse konu kararlar incelendiğinde; güneş enerjisi bakımından önemli bir potansiyel taşıyan kentte yeni yapılacak yapıların tasarımında güneşe yönelim kararlarına yer verildiği görülmektedir. Bunun yanı sıra; sıcaktan korunmak amacıyla yapıların tasarımında avlu öğesine yer verilmesi iklim özelliklerine uygun kararların alındığını göstermektedir. 
Strateji Belgesi'nde; göç ile birlikte nüfusu artan ve karma sosyal bir yapıya sahip olan kente ilişkin özellikle sosyal konulara yer verilmiştir. Saha çalışmaları sırasında anket, mülakat ve gözlemler ile yerli halkın göçmenlere ilişkin sorunları ve göçmenlerin beklentileri tespit edilmiştir. Toplanan veriler ve sonrasında yapılan analizler neticesinde göçmenler ile yerel halk arasında dil, kültür ve yaşam tarzından kaynaklanan sorunların olduğu tespit edilmiştir. Belge ile göçmelerin kentte karşı karşıya oldukları sorunları çözmek ve bunun yanı sıra; sosyal hayata katılımlarını kolaylaştırmak hedeflenmiştir. Sosyal konulara yer veren belgenin sürdürülebilirliğin her üç boyutunu da ele alan bir belge olduğu söylenemez. Daha çok sosyal konulara değinen belgede ekonomik boyut göz ardı edilmiştir. Ekonomik, sosyal ve yapılaşmış çevre arasında denge kurmayı amaçlayan kararlara yer verilmemiştir.

Kaynakların korunması ve yönetimi konusu değerlendirildiğinde; her ne kadar iklime duyarlı, sürdürülebilir kentlerin oluşturulması amaçlanmış olsa da, belirlenen stratejiler biyolojik çeşitliliğin korunması açısından değerlendirildiğinde yetersiz kalmaktadır.

Diğer taraftan, Kilis Kentsel Dönüşüm Strateji Belgesi'nde yalnızca üst ölçekli kararlara yer verilmiş olup, alınan kararların birçoğu mekana yansıtılamamıştır. Ancak Elazığ ìli ve İstanbul İli, Gaziosmanpaşa İlçesi için hazırlanan Master Planlar incelendiğinde alınan kararların mekana yansıtıldığı görülmektedir.

Kilis benzeri sınır kentlerinde göçmenlerin demografik yapısının analiz edilerek göçün doğru şekilde planlanması ve yönetilmesi önemlidir. Göçmelerin kayıt altında tutulması, göçün planlanması gerekmektedir. Göç ile gelenlere verilecek hizmetlerin demografik yapıya göre belirlenmesine ilişkin kararlar alınmalıdır. Hizmetlerin belirlenmesinin yanı sıra; kentin yerleşim alanları planlanırken de yaş, cinsiyet, etnik yapı ve gelir durumu vb. demografik özellikler göz önünde bulundurulmalıdır. Göçmenler için planlanan konut alanlarının konumları ve nitelikleri sosyal hayata entegre olmaları için önemlidir.

Sit Alanlarından oluşan kent merkezinin dolması ile birlikte kentte konut alt bölgeleri oluşmaya başlamıştır. Kaçak yapılaşan kente ilişkin 6306 sayılı Kanun kapsamında dönüştürülmesi öngörülen teklif riskli alanlar belirlenmiştir. Böylelikle kentsel dönüşüm projeleri ile; Kilis Kenti genelinde konut alanları iyileştirilerek, konut kalitesi artırılacaktır. Bu açıdan değerlendirildiğinde; kentsel dönüşüm ile kentsel sorunları çözmeye ilişkin konut stoku ve kalitesinin artırımasının hedeflendiği görülmektedir. Kentsel dönüşüm uygulama alanlarında mevcut konut tipolojisine uygun konut üretimin yapılması önerilmektedir.

Sonuç olarak Kilis özelinde göçmenlerin yönetilmesine ilişkin doğru kararlar alınması ve göçmenlerin sosyal hayat entegre olmaları için ilgili kurum ve kuruluşların görev ve sorumluklarının tanımlanması gerekmektedir. Diğer taraftan; kentin sahip olduğu değerlerin korunmasını, afet risklerinin bertaraf edilmesini, sürdürülebilirlik ilkelerinin mekana yansıtılmasını hedefleyen belgelerin ekonomik, ekolojik, mekânsal tüm sorunlara değinen bir belge olması gerektiği düşünülmektedir. Kilis Kentsel Dönüşüm Strateji Belgesi'nde yer alan kararların hayata geçirilebilmesi yasal düzenlemelerin yapılması ile mümkün olacaktır. Hazırlanan Kentsel Dönüşüm Strateji Belgesi, kentsel sorunların çözümlenmesini sağlayan, fiziksel boyutta kalmayıp, ekonomik, sosyal ve çevresel konulara da değinen bir çalışmadır. Söz konusu belgenin uluslararası düzeyde gerçekleştirilen çalışmalara yaklaştığı görülmektedir.

Uluslararası literatürün incelenmesi sonucu oluşturulan uyumluluk matrisi ile birlikte belirlenen, kentsel dönüşüm strateji belgelerinde yer alması gerektiği düşünülen sosyal, ekonomik, yapılaşmış ve doğal çevre sürdürülebilirlik ilkeleri aşağıda yer almaktadır. 
Sosyal Sürdürülebilirliğin; Yoksulla mücadeleye yönelik eylemlerin belirlenmesi, eğitim ve sağlık hizmetleri vb. donatı alanlarının kapasitesi ve kalitesinin geliştirilmesi, demografik özellikler dikkate alınarak (cinsiyet, yaş ve gelir) yerleşimlerin planlanması, planlama sürecinde halkın katılımın sağlanması, göçün planlanması, dezavantajlı grupların beklentilerin analiz edilmesi, yerel yönetimlerin görev ve sorumluluklarının belirlenmesi, çiftçilerin desteklenmesi, tarihi ve kültürel değerlerin korunmasına ilişkin kararlar alınması ile,

Ekonomik Sürdürülebilirliğin; Tüketici mevzuatlarının düzenlenmesi, tüketicilerin ürünlerin çevreye etkilerine yönelik bilgilendirilmesi, geleneksel ve yöresel ürünlerin üretilmesine ilişkin teşviklerin sağlanması, ekonomide ulusal ve uluslararası işbirliğinin hedeflenmesi, alternatif enerji kaynakları kullanılarak enerji verimliliğinin artırılması ile,

Yapılaşmış ve Doğal Çevrenin Sürdürülebilirliğinin ise; Afet riski altında bulunan alanların tespit edilerek önceliklendirilmesi, üst ölçekli planlarda afet sonrası toplanma alanlarının belirlenmesi, sürdürülebilir ulaşım sistemlerinin geliştirilmesi, yerel potansiyellerin değerlendirilerek, alternatif enerji kaynaklarının kullanılmasına ilişkin kararlar alınması gerekir. Topografya ve iklim göz önünde bulundurularak arazi kullanım planının yapılması, kentsel tasarımda bölgesel iklim özelliklerinin göz önünde bulundurulması, sera gazı etkisini azaltan projelerin üretilmesi, hava, su ve toprak ekosistemin korunmasına ilişkin kararların alınması, zehirli kimyasal atıkların, katı atık ve atık suların yönetilmesi ve değerlendirilmesi ilişkin kararların alınması şarttır. Yıkılıp yeniden yapılaşacak olan alanlarda yıkım esnasında ortaya çıkacak atıkların yönetilmesine ilişkin eylemlerin belirlenmesi önemlidir.

Böylelikle, afet riski altındaki dönüşüme intiyaç duyan alanlara ilişkin hazırlanan kentsel dönüşüm strateji belgelerinde sürdürülebilirlik yaklaşımlarının benimsenmesi ile birlikte ekolojik, mekansal, ekonomik, sosyal ve kültürel sürdürülebilirliği sağlamaya yönelik bir adım atılmış olacaktır. 


\section{KAYNAKLAR}

6306 sayılı Afet Riskli Altındaki Alanların Dönüştürülmesi Hakkında Kanun.

Agenda 21, (1992). United Nations Sustainable Development. Rio de Janerio, Brazil.

Akgün, A., A., Alkay, E., Kerimoğlu, E., Koramaz, T., K., Kundak, S., Okumuş, G., Özçevik, Ö. (2014). Şehir planlamada analiz ve değerlendirme teknikleri, (Ed. Elif ALKAY), (s. 151163 içinde.

Altun F, Birinci, M. (2015). Disiplinlerarası göç ve göç politikalarının değerlendirilmesi, (Ed. Canatan, K., Birinci, M., Çağlar, İ., Kryvenko, Y., Öksüz, S., Altun, F.), Suriyeli Sığınmacılara Yönelik Sosyal Yardım ve Sosyal Hizmet Uygulamalarının Göç Yönetimi Bağlamında Değerlendirilmesi (s.103-132) içinde.

Altuntaş, A. (2012). Sürdürülebilir toplumlar ve metropollerin baskılarından kurtulmak lçin alternatif bir yol: sürdürülebilir kentler. Mustafa Kemal Üniversitesi Sosyal Enstitüsü Dergisi, 9 (17) (s. 135-148) içinde.

Ataöv, A., Osmay, S. (2007). Türkiye'de kentsel dönüşüme yöntemsel bir yaklaşım. METU JFA, 2007-2, 24(2) (s. 57-82) içinde.

Bilgili, M.,Y. (2017). Ekonomik, ekolojik ve sosyal boyutlarıyla sürdürülebilir kalkınma. Uluslararası Sosyal Araştırmalar Dergisi, 10 (49) (s. 559-569) içinde.

Coaffee, J. (2008). Risk, resilience, and environmentally sustainable cities. Energy Policy, 36, (s. 4633-4638) içinde.

Çevre ve Şehircilik Bakanlığı (ÇŞB). (2015). Kilis kentsel dönüşüm strateji belgesi.

Çevre ve Şehircilik Bakanlığı (ÇŞB). (2019). Kentsel dönüşüm strateji belgesinin hazırlanmasına yönelik ilke ve esaslar.

Ercoşkun, Ö.Y., Karaaslan Ş. (2011). Next-generation urban design guides for sustainability of small towns: A case study on Güdül, Turkey. Urban Design International, 16(2) (s.105124) içinde.

EU. (2004). Urban design for sustainability, Final report of the working group on urban design for sustainability to the European Union Expert Group on the urban environment. Austria.

Fırat, F., K., Akbaş, F. (2015). Inşaat endüstrisinde geri dönüşüm çalışmalarının geliştirilmesi ve ekonomi üzerine etkileri. Session 4D Çevre ve Enerji,(s. 637-644) içinde.

Gazibey, Y., Keser, A., Gökmen, Y. (2014).Türkiye'de illerin sürdürülebilirlik boyutları açısından değerlendirilmesi. Ankara Üniversitesi SBF Dergisi, 69 (3) (s.511-544) içinde.

Godschalk, D.R. (2003). Urban hazard mitigation: creating resilient cities. Natural Hazards Review ASCE, 4(3) (s. 136-143) içinde.

http://www.cem.gov.tr/erozyon/Cop12_belgeler/collesmeilemucadelesozlesmesivecollesmeol gusu.aspx?sflang=tr

Hodson, M., Marvin, S. (2009). Urban ecological security: a new urban paradigm?. Int. Journal of Urban and Regional Research, 33(1) (s. 193-215) içinde.

Holmgren, D. (2007). Permaculture: principles and pathways beyond sustainability. Australia: Holmgren Design Services. 
Hopkins, R. (2008). The transition handbook. Devon, UK: Green Books.

İpekyolu Kalkınma Ajansı. (2015). TRC1 Gaziantep, Adıyaman, Kilis Bölge Planı 2014-2023.

Kandaloğlu, N. (2012). Kentsel Dönüşüm ve Bir Dağıtım Modeli Önerisi (Yüksek Lisans Tezi). İstanbul Teknik Üniversitesi, Fen Bilimleri Enstitüsü.

Kazimee, B.A. (2002). Sustainable urban design paradigm: twenty five simple things to do to make an urban neighborhood sustainable, (Ed. C.A. Brebbia, C. Martin-Duque, L.C. Wasdhwa), The Sustainable City II, (s. 31-41) içinde. London: Witpress.

Newman, P., Jennings, I. (2008). Cities as sustainable ecosystems principles and practices. Washington DC: Island Press.

Newman, P., Beatley, T., Boyer, H. (2009). Resilient cities responding to peak oil and climate change. Washington DC: Island Press.

Raven, J. (2010). Cooling the public realm climate-resilient urban design. Paper presented at the meeting of 1 st World Congress on Cities and Adaptation to Climate Change Resilient Cities 2010, Bonn, Germany.

Resilientcity websitesi, 8 Ağustos, 2010 http://www.resilientcity.org/index.cf m?pagePath=RESILIENCE\&id=11449.

Okumuş, D. E., Eyüboğlu, E. E. (2015). Kentsel dönüşüm öncesi kentsel yaşam kalitesi araştırmasına yönelik yöntem önerisi ve Ataşehir Barbaros Mahallesi örneklemi. Planlama 2015, 25 (2) (s. 93-106) içinde.

Ortadoğu Stratejik Araştırmalar Merkezi (2015). Suriyeli sığınmacıların Türkiye'ye etkileri (Rapor No. 195). Ankara.

Şişman, A., Kibaroğlu, D. (2009). Dünyada ve Türkiye'de Kentsel Dönüşüm Uygulamaları, Ankara: TMMOB Harita ve Kadastro Mühendisler Odası 12. Türkiye Harita Bilimsel ve Teknik Kurultayı.

United Nations international strategy for disaster reduction (UNISDR). (2010). Making cities resilient: my city is getting ready. 2010-2011 World Disaster Reduction Campaign Report. Geneva: UN.

Yedekçi Arslan, G. (2014). Kentsel dönüşümün sürdürülebilirlik boyutu: Hammarby (İsveç) ve Fener Balat örneklerinin incelenmesi. Artium, 2 (2) (s. 180-190) içinde.

Yinanç, A. (2018). Uluslararası yönetim, ekonomi ve politika kongresi 2018 bahar tam metin bildiriler kitabı. (Ed. Erdoğan, S., Yıldırım, D., Ç. ve Gedikli, A.) Ani Göç Akınının Kentlerimizin Altyapısına Getirdiği Yükler ve Çözüm Önerileri (s. 375-383 içinde).

Wheeler, S. M.,(2004). Planning for sustainability. 1.Baskı, London: New York.

Varol, Ç., Ercoşkun, Ö.Y., Gürer, N. (2011) Local participatory mechanisms and collective actions for sustainable urban development in Turkey, Habitat International, 35(1) (s. 9-16) içinde.

Vergunst, P. J. B. (2002). The potentials and limitations of self-reliance and self-sufficiency at the local level: views from Southern Sweden. Local Environment, 7(2) (s.149-161) içinde. 